This is an open access article under the CC BY-NC-ND license (https://creativecommons.org/licenses/by-nc-nd/3.0/) Issue III, November 2020

ISSN 2707-9481

ISBN 978-601-323-207-2

https://doi.org/10.31643/2020.020

\author{
Dinara Zhulamanova \\ Abai Kazakh National Pedagogical \\ University, Kazakhstan \\ E -mail: zhakdinara@mail.ru \\ ORCID ID: https://orcid.org/0000-0001-6996-1297
}

\title{
The Role of Forming a Management Model in Educational Organizations
}

\begin{abstract}
The theory of modern school management is developed as part of the general theory of social institutions management. Very important changes are expected in the system of financing and management of education in accordance with modern requirements. The object and subject of management is a person. The article states that the basic principles and regularities of the management process are generally reflected in all public structures. However, when managing any organization at the request of the manager, the management model is applied to this organization and its staff. And modern management models differ in creating conditions for employees. Accordingly, the author considers the importance and relevance of forming their own management model in relation to the organization of education. The author analyzes the management models of various foreign countries, factors that determine the national management model and formulates their main ideas.
\end{abstract}

Key words: human resource, educational organization, management model, personnel management.

Cite this article as: Zhulamanova D., (2020). Bilim berw uyımdarında basqarw modelin qalıptastırw röli [The Role of Forming a Management Model in Educational Organizations]. Challenges of Science. Issue III, p.: 145-149. https://doi.org/10.31643/2020.020

\author{
Динара Жуламанова \\ Абай атындағы ҚазҰПУ, Қазақстан \\ E-mail: zhakdinara@mail.ru \\ ORCID ID: https://orcid.org/0000-0001-6996-1297
}

\section{Білім беру ұйымдарында басқару моделін қалыптастыру рөлі}

Абстракт. Қазіргі заманғы мектепті басқару теориясы әлеуметтік мекемелерді басқарудың жалпы теориясының бір бөлігі ретінде дамиды. Заман талабына сай білім беруді қаржыландыру және басқару жүйесінде өте маңызды өзгерістер күтілуде. Басқарудың объектісі мен субъектісі - адам. Мақалада басқару үрдісінің басты ұстанымдары, заңдылықтары барлық қоғамдық құрылымдарда жалпылама түрде кездесетіні жайлы айтылған. Дегенмен кез-келген ұйымды басқару барысында басшының қалауы бойынша сол ұйымға және қызметкерлерге қатысты басқару моделі қолданылады. Ал заманауи басқару модельдері қызметкерлерге жағдай жасау арқылы ерекшеленеді. Сәйкесінше білім беру ұйымына қатысты өзіндік басқару моделін қалыптастыру маңыздылығы мен өзектілігі қарастырылады. Автор әртүрлі шет елдердің басқару моделдеріне, ұлттық басқару моделін анықтайтын факторларға талдау жасайды және олардың негізгі идеяларын тұжырымдайды.

Түйінді сөздер: адам ресурсы, білім беру ұйымы, басқару моделі, кадрлық менеджмент. 


\section{Kipicпе}

2020-2025 бағдарламасы бойынша Қазақстандық білім мен ғылымның жаһандық бәсекеге қабілеттілігін, білімнің сапасын арттыру көзделген. Міндеттің орындалуы мақсатында Қазақстан елі дүниежүзілік деңгейде экономиканың, инфрақұрылымдық жүйелердің дамуына жауап бере алатындай білім беру керек [1]. Осы орайда білім беру саласында көптеген реформалар жасалуда және жүзеге асырылуда. Қазіргі таңда Қазақстан Республикасының Білім және ғылым министрлігінің мәлімдеуі бойынша қаржыландыру және білім беруді басқару жүйесінде өте маңызды өзгерістер күтілуде, яғни мемлекет басшысының 2019 жылғы тамыз конференциясында берген тапсырмалары аясында білім беру жүйесін басқару моделін өзгертуде. 2021 жылдан бастап барлық білім бөлімдері - аудандық және қалалық - облыстық басқарма деңгейіне беріледі. 2021 жылдан бастап бұл жаңа жүйенің жұмыс істеуі жоспарлануда [2]. Білім беру ұйымдарын басқару, яғни білім сапасын, мектептің материалдық және қаржылық жағдайын қадағалау сияқты мәселелерді шешу Қазақстан Республикасының заңнамасына, тиісті үлгідегі білім беру ұйымы қызметінің үлгілік ережелері мен білім беру ұйымының жарғысына сәйкес жеке-дара басқару және алқалылық принциптерімен жүзеге асырылады [3]. Ал білім беру ұйымының қызметкерлерін басқару моделі заман талабына сай жетілдірілуі қажет.

\section{Негізгі бөлім}

Қазіргі заманғы мектепті басқару теориясы әлеуметтік мекемелерді басқарудың жалпы теориясының бір бөлігі ретінде дамиды. Оның өнеркәсіптік сияқты мекемелерді басқарудан айырмашылығы бар болғанымен, негізі бір. Жалпы басқару - диалектикалық үрдіс. Өзіндік ерекшелігі бар ғылымға айналғанға дейін бірнеше даму тарихынан өтті. Сондықтан да басқару туралы алғашқы идеялардың тамыры тереңде жатыр. Ал қазір кеңінен қолданылатын басқару теориясы XX-ғасырдың бас кезінде «менеджмент» ұғымымен толықтырылды. Менеджменттің құрылымы басқару теориясынан бөлек тәжірибелік білім, адамның психологиясын ажырату компоненттерінен тұрады [4,б.13].

Басқару үрдісінің басты ұстанымдары, заңдылықтары барлық қоғамдық құрылымдарда жалпылама түрде кездесіп отырады. Ең алдымен, басқарудың ұйымдастырушылық-басқарушылық, ынталандырушылық, әлеуметтік- психологиялық түрлері кез келген мекемеге, ұйымдарға тән. Басқарудың объектісі мен субъектісі - адам. Адам басқарудың субъектісі ретінде қоғамда әртүрлі қызмет атқарады, басқару ісіне белсенді түрде араласып, қоршаған ортадағы мәдени-қоғамдық, әлеуметтік жағдайларға байланысты айналасымен тығыз қарым-қатынаста болады. Қызметкердің басқару объектісі ретіндегі көзқарас, ұйымдардағы адам ресурстарын басқаруда қолданылатын жүйені анықтайды. Педагогика ғылымының профессоры Т.М. Баймолдаев өзінің еңбегінде басқару түсінігіне анықтама бере отырып, мынадай қорытынды жасайды: «Жалпы білім беретін мектепті басқару дегеніміз - бұл ғылыми -педагогикалық және ұйымдастырушылық функциясы сәйкес келетін, жас ұрпақты әлеуметтік- экономикалық және ұйымдастырушылық- педагогикалық процесте оқытып тәрбиелейтін мектеп ісін тиімді ұйымдастыру» [4,б.47].

Мектепішілік басқару жүйесі- педагогикалық жүйенің жүйесі, яғни әдістемелік жүйе мен педагогикалық қызмет негізінде оқыту үрдісін ұйымдастыру. Қарым-қатынас, байланыс, арнайы нысандар арқылы функциялар жүзеге асып, мектепті дамытуға және қамтамасыз етуге бағытталған әр түрлі деңгейдегі басшылардың өзара іс-қимылының ұйымдық құрылымы.

Жалпы білім беретін мектепті басқару ісінде төмендегідей: ғылымилық, мақсаттылық, алқалық (бірлесе шешім қабылдау), демократияландыру (жариялылық), бірегей бастаушылық, өкілеттілікті жауапты адамдарға жолдау, жүйелілік, жекелей жауапкершілік, табиғи үйлесімділік, жеке тұлға ретінде қарау сияқты қағидалар басшылыққа алынады. Осы бағыттағы басқару ісінде кешендімақсатты жоспарлау, проблемалық-бағдарлы талдау, басқару мониторингісінің жүйесін құру, авторлық тереңдетіп оқыту бағдарламаларын әзірлеу және оны ресми түрде мақұлдау т.б. сияқты көптеген жаңалықтар ендірілуде[4,б.154].

Басқару жүйесі педагогикалық үрдіске ұйымдастыру және басқару арқылы әсер етеді. Кадрларды басқару қазіргі заманғы менеджменттің негізгі құрамдас бөліктерінің бірі болып табылады. Кадрларды басқару- бұл ұйымды өзіне жүктелген еңбек қызметтерін сапалы орындауға қабілетті, білікті мамандармен қамтамасыз етуге және кадрларды оңтайлы пайдалануға бағытталған практикалық қызмет [5].

Кез-келген ұйымды басқару барысында басшының қалауы бойынша сол ұйымға және қызметкерлерге қатысты басқару моделі қолданылады. Ұйымды басқару модельдері сыртқы ортаның әсерінен де, ішкі себептермен де өзгеретін динамикалық құрылымдар болып табылады. Бұл эксперименттердің бір түрі, онда көшбасшы мүмкін болатын әр түрлі ең жақсы басқару әсерін 
таңдайды. Модель-бұл ұйымның жағдайын көрсету тәсілі ғана емес, сонымен қатар жұмыс объектісі. Модель-бұл объектінің (түпнұсқаның) және субъектінің (тікелей модельдеумен айналысатын адамның) өзара әрекеттесуі кезінде алынған нәтиже. Ұйымды басқару моделі деп теориялық тұрғыдан нығайтылған пікірді түсіну керек: басқару жүйесінің мәні мен негізгі принциптері туралы; оның басқарылатын объектіге әсері туралы; басқару жүйесінің компанияның алдында тұрған мақсаттарының орындалуын қамтамасыз ететіндей, өміршең және тұрақты дамитындай етіп қоршаған әлемдегі өзгерістерге бейімделуі туралы [6].

Ұйымды басқарудың негізгі модельдері мыналарды қамтиды: менеджменттің негізгі ережелері; стратегиялық көзқарас - кәсіпорынның ұзақ мерзімді болашағын оның негізгі фигуралары қалай көретіні; мақсаттары мен міндеттері; жеке әзірленген ұйымның құндылықтарының тізімі; құраушы элементтердің иерархиясы және олардың бір-бірімен өзара әрекеттесу принциптері; корпоративтік және ұйымдастырушылық мәдениет.

Жалпы ұйымды басқару жүйесінің алты негізгі моделі бар:

1. Сызықтық-функционалды басқару моделі компанияның құрылымдары

мен қызметкерлері арасындағы функционалдылықты қатаң бөлуді және шоғырландыруды білдіреді. Бекітілген міндеттер ұйымның негізгі құжатында - жарғыда, қызметкерлердің лауазымдық нұсқаулықтарында сипатталған және қатаң түрде орындалуы керек.

2. Штаттық немесе директивалық модель қызметтер мен қызметкерлер

лауазымдық нұсқаулықтар мен құрылымдық бөлімшелер туралы ережелер негізінде жұмыс істейді деп болжайды. Менеджменттің иерархиялық ұйымдық құрылымы бар және жұмыс процесі осы құрылымнан жоғарыдан төменге қарай берілетін бұйрықтардың көмегімен реттеледі.

3. Жобалық басқару моделі басқару жүйесі дәйекті және белгілі бір

мақсатта өзгеретін компанияларға тән. Бұл мәселені шешу немесе жобаны орындау үшін бірлескен қызмет үшін арнайы бөлімдер немесе жұмыс топтарын ұйымдастыруды қамтиды.

4. Матрицалық басқару моделі-сызықтық-функционалды және жобалық

модельдердің жиынтығы. Мұнда орындаушылар үшін қос бағыну ережесі енгізіледі: олар желілік қызмет аясында тікелей басшының алдында және жұмыс жобасының тікелей иесінің алдында жауап береді.

5. Менеджменттің сервистік моделі жоба менеджерлерінің қызметтерге

желілік бөлімшелерге жүгінуге құқығы бар, ал олар жоба үшін алынған қаражаттан туындаған шығындарды қаржыландырады.

6. Үдеріске бағдарлауды басқарудың таза моделі ретінде басқару, өндіріс

және қамтамасыз ету арасындағы тығыз байланысты қамтиды. Бұл модельде жоба менеджерлеріне үдерістің тиімділігі мен тиімділігіне бағынатын ресурстар беріледі [7].

Дегенмен менеджменттің териясы мен практикасы көптеген өзгерістерге ұшырауда. Басқару моделінің қалыптасуына көптеген факторлар айтарлықтай әсер етеді. Олар келесідей: менталитет және ұлттық мәдениет; қолданыстағы өндіріс әдісі; меншік нысандары, қоғамдық- саяси құрылымы; ұлттық басқару тәжірибесі; рухани даму; әлемдік басқарудың заңдылықтары [6].

Қазіргі таңда ұйымдарда жүзеге асырылатын классика деп атауға болатын тек қызметкерге бағытталған американдық басқару стратегиясы, ұжымдық жұмысты негізге алатын жапондық басқару моделі, сонымен қатар аралас түрде жүзеге асырылатын жаңа маркетингтік (немесе ақпараттық) модельдер белгілі Жоғарыда келтірілген факторларға сүйенетін болсақ, бұл ұлттық мәдениетке тән модельдер және бір-біріне деген қатынаспен ерекшеленеді. Сонымен қатар жауапкершілікті табыстау және құзыреттіліктерді дамыту негізінде төмендегідей басқару модельдерін көруге болады. Алғашқы англо-американдық моделі: үздіксіз оқытуға негізделеді, ал неміс басқару моделі: барлық үдерістерді қатаң реттеу, өкілдік ұйымды басқару әдістері швед моделіне негізделуі мүмкін[7]. Бұл менеджерден орындаушыларға өкілеттік беруді қамтиды, өйткені менеджер кәсіпорынның барлық ұсақ мәселелерінде физикалық тұрғыдан құзыретті бола алмайды.

Заманауи басқару модельдері қызметкерлерге жағдай жасау арқылы ерекшеленеді. Білім беру саласының кадрлық менеджментке қатысты үлкен қадам ол- «Педагог мәртебесі туралы» Қазақстан Республикасының заңы. Білім беру саласындағы кәсіби қызметті жүзеге асыратын педагогтер бірыңғай мәртебеге ие және өзара кәсіби қызмет ерекшеліктерімен өзгешеленеді. Педагогке өзінің кәсіби қызметін жүзеге асыруы үшін қолайлы жағдайлар жасалады [8]. Ол дегеніміз адам ресурсын - баға жетпес құндылық деп бағалау.

Американдық оқытушы «Жасампаз адамдардың жеті дағдысы» атты еңбектің авторы, басқару, өмірді басқару, ұйымдастырушылық басқару бойынша кеңесші Стивен Р. Кови менеджментке қатысты былай деген: «Менеджмент - тірек нүктесін жылжыту, ал табыстау - тиімді менеджменттің кілті». 
Өйткені басшы қызметкеріне істі табыстау барысында оның мүмкіндіктеріне назар аударады, ал ол дегеніміз қандайда істі басқаруды табыстау барысында әдіске емес, нәтижеге мән береміз [9,б.170]. Сәйкесінше сенім артқанды көрсетеді. Сенім- бұл адамды ынталандырудың ең тиімді түрі. Ол адам бойындағы бар жақсысын көрсетеді. Бірақ сенім уақыт пен шыдамдылықты қажет етеді. Сонымен қатар қабілет сенімге сай болу үшін, адамдарды оқыту мен дамыту қажеттігін жоққа шығармайды. Жалпы сенім арттыру арқылы нәтижеге бағытталу кезінде қызметкер мен басшы «ұтады». Яғни бұл адамдар арасындағы қарым-қатынасты жалпы қамтитын парадигма.

Менеджмент адам ресурстарын басқару барысында жеті негізгі ұсынысты бөліп көрсетеді: қызметкерлердің жұмысын жоспарлау, олардың жұмыстағы өмірін талдау және түсіну; өнімділікті арттыру және қызметкердің өмірін жақсарту үшін HR технологиясын қолдану; цифрландыру қозғалысын басқару; икемді және командалық бағытталған ұйымдастырушылық модельдерді түсініп, қолдану; сенім, бірлік, ортақ мақсаттар мен ашықтық мәдениетін қалыптастыру үшін басшылықпен жұмыс жасау; HR және басқа бөлімдер арасындағы алшақтықты бұзып, командалық желі ретінде жұмыс істеу үшін персоналды басқару қызметін жоспарлау; қызметкерлерді рухани жандандыру, кәсібилендіру және үнемі жетілдіру[10].

\section{Қорытынды}

Білім беру саласындағы басқару моделін қалыптастыру барысында ең алдымен педагогикалық үрдіске баса назар аударамыз. Ал педагогикалық үрдістің басты тұлғасы - мұғалім. Мұғалім оқушыға білім береді, сонымен қатар кез келген реформалау іс-шаралары мен идеяларын іске асыра алады. Сондықтан басқарудағы ең басты мақсаты ретінде мұғалімдердің кәсіби өсуіне, ғылыми ізденіс жағдайындағы шығармашылықпен жұмыс жасауына, потенциалын ашу мен қалыптастыруға, істәжірибелерін насихаттауға жағдай жасау және ықпал ету басқарудың басты нысаны болуы тиіс [4,б.154]. Білім беру ұйымының басшысы заманауи басқару моделін таңдау барасында ең басты назарды қызметкерге аударады, нәтижеге бағытталады, ал қызметкер өз тарапынан проактив болуы шарт. Проактив жай белсенді болудан әлдеқайда кең мағына. Ол дегеніміз «Адам болып туған соң, өз өмірімізге жауаптымыз» дегенді білдіреді. Жасампаз жандар жауапкершіліктен жалтармайды[9,б.79]. Жауакершілікпен кез-келген жұмысты атқарады. Сонымен білім беру саласындағы арнайы басқару моделін қалыптастыру қызметкердің дамуы мен кәсіби өсудің негізгі тетігі және жалпы білім беру сапасының артуына ықпал етеді.

Мақалаға сілтеме: Жуламанова Д., (2020). Білім беру ұйымдарында басқару моделін қалыптастыру рөлі. Challenges of Science. Issue III, p.: 145-149. https://doi.org/10.31643/2020.020

\section{Әдебиеттер}

1. азақстан Республикасында білім беруді және ғылымды дамытудың 2020 - 2025 жылдарға арналған мемлекеттік бағдарламасы. https://adilet.zan.kz/kaz/docs/P1900000988

2. «С 2021 года все отделы образования будут переданы на уровень областного управления». https://www.zakon.kz/5025910-s-2021-goda-vse-otdely-obrazovaniya.html

3. Қазақстан Республикасының « Білім туралы» 2007 жылғы 27 шілдедегі № 319-ІІІ Заңы http://adilet.zan.kz/kaz/docs/Z070000319_\#z51

4. Баймолдаев Т.М. (2009) « Мектеп басқару: даму тарихы, ғылыми және әдіснамалық негіздері, тәжірибесі», Алматы

5. Zhulamanova D. (2020) Importance of managing the professional development of young teachers. Challenges of Science. Issue III, 2020. Рp.: 115-117. https://doi.org/10.31643/2020.016

6. «Модели управления как форма эволюции управленческой мысли» https://studref.com/354123/menedzhment/modeli_upravleniya_forma_evolyutsii_upravlencheskoy_mysli

7. «Модели управления организацией: как построить свою уникальную» https://www.gd.ru/articles/8625-modeliupravleniya-organizatsiey

8. «едагог мәртебесі туралы» (2019) - Қазақстан Республикасы Заңының жобасы Қазақстан Республикасы Үкіметінің жылғы 31 тамыздағы № 645 қаулысы. http://adilet.zan.kz/kaz/docs/P1900000645 
9. Стивен Р. Кови (1994) «Жасампаз адамдардың жеті дағдысы». FranklinCovey Company,- Алматы: Ұлттық аударма бюросы. - 2018 жыл.- 352бет.

10. «HR в меняющемся мире: семь высокоэффективных методов управления персоналом» https://hh.kz/article/505205

\section{References}

1. Kazakstan Respublikasynda bilim berudi zhane gylymdy damytudyn 2020-2025 zhyldarga arnalgan memlekettik bagdarlamasy. http://adilet.zan.kz/kaz/docs/P1900000988

2. «S 2021 goda vse otdely obrazovaniya budut peredany na uroven oblastnogo upravleniya.». https://www.zakon.kz/5025910-s-2021-goda-vse-otdely-obrazovaniya.html

3. Kazakstan Respublikasynyn «Bilim turaly» 2007 zhylgy 27 shildedegi № 319 -III Zany https://adilet.zan.kz/kaz/docs/Z070000319_\#z51

4. Baimoldayev T.M. (2009) «Mektep baskaru: damu tarihy, gylymi zhane adisnamalyk negizderi, tazhiribesi», Almaty

5. Zhulamanova D. (2020) Importance of managing the professional development of young teachers. Challenges of Science. Issue III, 2020. Pp.: 115-117. https://doi.org/10.31643/2020.016

6. «Modeli upravleniya kak forma evolucii upravlencheskoi mysli» https://studref.com/354123/menedzhment/modeli_upravleniya_forma_evolyutsii_upravlencheskoy_mysli

7. «Modeli upravleniya organizaciei: kak postroit svou unikalnuyu» https://www.gd.ru/articles/8625-modeli-upravleniyaorganizatsiey

8. «Pedagog martebesi turaly» (2019) - Kazakstan Respublikasy Zanynyn zhobasy, Kazakstan Respublikasy Ukimetinin zhylgy 31 tamyzdagy № 645 kaulysy. http://adilet.zan.kz/kaz/docs/P1900000645

9. Stiven R. Kovi (1994) «Zhasampaz adamdardyn zheti dagdysy». FranklinCovey Company,- Almaty: Ultyk audarma burosy. - 2018 zhyl.- 352bet.

10. «HR v menyaushemsya mire: sem vysokoeffektivnyh metodov upravlenya personalom», https://hh.kz/article/505205. 